\title{
The Political Economy of Australia's Waste Crisis: From Neoliberalism to the Circular Economy Agenda
}

\author{
Wynston Joon Yuen Lee ${ }^{1}$ (D)
}

Received: 5 April 2021 / Accepted: 19 July 2021/Published online: 04 November 2021

(C) Springer Nature Switzerland AG 2021

\begin{abstract}
The international trade of waste has come under public spotlight in recent years with China, the world's main waste sink for several decades, effectively banning its waste imports in 2018 and subsequently starting a waste crisis in Australia. This article compares the perspectives of orthodox economics, circular economy and political economy on waste economics and policy in Australia. Taking an approach combining both qualitative and quantitative analysis, this article finds that the political economy of Australia's waste crisis can be understood in terms of two phases: (1) an expansionary phase in Australia's waste industry from the 1990s onwards, driven by export-oriented growth and neoliberal policy which ultimately led to a waste crisis in 2018, and (2) an emerging recovery stage for the industry led by circular economy policy and more domestically oriented development. These findings contribute to ongoing discourse on the circular economy agenda, demonstrating that in the case of Australia's waste crisis, circular economy is more of a pragmatic strategy to stimulate economic recovery rather than some radical change towards environmental sustainability.
\end{abstract}

Keywords Waste policy · Waste crisis · Waste trade · Circular economy · Political economy · Product stewardship $\cdot$ Australia $\cdot$ Neoliberalism

\section{Abbreviations}

CE Circular economy

E-waste Electronic waste

EoL End-of-life

WEEE Waste electrical and electronic equipment

PSS Product stewardship scheme

NTCRS National Television and Computer Recycling Scheme

Wynston Joon Yuen Lee

wynston.lee@outlook.com

1 RMIT University, Melbourne, VIC 3000, Australia 


\section{Introduction}

At the most basic level, waste is generated as an entropic by-product of economic production, consumption and distribution. Though low in value and often hazardous, waste is usually treated by orthodox economists as just another externality that can be priced in the market and thus have its social and environmental harms adequately resolved.

This orthodox economic logic intensified during the neoliberal era as the international waste trade massively expanded, seen in Australia through athe quadrupling of waste exports in the 7 years from 1999-2000 (\$349m AUD) to 2006-07 (\$1,245m AUD). Growth in the international waste trade has been most evident in China, with $45 \%$ of the world's cumulative plastic waste from 1992 onwards ending up within its borders [1]. China has been addressing the harms from its waste imports for over a decade through various national policies, leading to its landmark "Blue Sky 2018" policy ultimately disrupting the international waste trade by forcing developed, net waste-exporting countries to find alternative waste markets, and encouraging developing, net waste-importing countries to follow China's lead and restrict their own waste imports [2]. The emergency of the issues around the trade of waste have been reflected around the world through upsurges media reports on the refusal of waste imports, growing diplomatic tension around the trade of waste, and the development of a research discourse that points not only to various nation-state waste crises but indeed a "global waste crisis" [3].

The structure of this article is as follows. The first section of this article compares the theoretical perspectives of orthodox economics, circular economy and political economy on waste management, with a particular focus on the Australian context. The second section applies government trade data to the theoretical framework of ecologically unequal exchange in order to analyse the economic and political forces which led to the expansion of, and subsequent crisis in, Australia's waste industry. The third and final section examines Australia's national product stewardship scheme for e-waste through a case study, leading to considerations for the future of circular economy in Australia's waste industry and beyond.

\section{Economic Context: Theoretical and Policy Perspectives}

Which theoretical approaches can best explain the economics of waste and its regulation in the case of Australia's waste crisis? This section assesses three key lines of economic thought and their respective policy implications in relation to waste and the environment: namely orthodox economics, circular economy and political economy.

To first briefly outline these theoretical perspectives, orthodox economists view waste as an externality that can be priced and thus efficiently managed through market mechanisms. From this framing, governments are required to intervene in the market through funding, taxation and infrastructure development in order to stimulate economic recovery. Next, the emergent circular economy concept draws from various schools of thought including industrial ecology, environmental economics and ecological economics in order to transition away from what they describe as the 'linear economy', instead towards a more 'circular' flow of energy and materials. Finally, political economy approaches to the environment focus on the systematic tendency for processes of capital accumulation to cause social and environmental crises. Here, the framework of ecologically unequal exchange is particularly relevant in the context of Australia's waste trade and subsequent crisis. 


\section{Orthodox Economics}

Industry and government perspectives on Australia's waste crisis have largely been informed by orthodox economics in their treatment of waste as an externality of economic development. Orthodox economics today can be defined as the 'neoclassical synthesis' between neoclassical microeconomics, and Keynesian macroeconomics [4]. Neoclassical microeconomics spurned various economic theories, with the supply and demand curve, general equilibrium and marginal analysis being most commonplace. Keynesian macroeconomics derives from Keynes' efforts to reduce unemployment during the First and Second World Wars, and argues for strong intervention from the state.

Orthodox economics' concept of market failure and negative externalities - situations where the market does not optimally allocate resources to the detriment of society and/or the environment, presents a clear picture of the theoretical tradition's influence on public policy. As an example to illustrate this point, the Australian federal government's report Plastics recycling: economic issues and implications reads not unlike an economics textbook: 'the social marginal costs of an activity are equated with the social marginal benefits' [5]. Consequently, the rationale for government intervention in situations of market failure is to correct market prices, a perspective that still holds strong today, as shown in a submission to the waste crisis senate inquiry by major Australian waste management company Visy:

Governments should implement a range of supportive policy reforms to enable the industry to continue to provide essential recycling and re-manufacturing services in the face of some major external disruptions and potential shocks [6].

Under the banner of 'neoliberalism', the influence of orthodox economics on public policy intensified during the 1980s as U.K. Prime Minister Thatcher and U.S. President Raegan worked to strengthen individual property rights and the institutions of free markets and free trade [4]. Reaching Australia's shores a decade later under the alternative banner of 'economic rationalism', this political ideology promoted the 'slimming of the state' through the enactment of policies such as privatisation, deregulation and trade liberalisation [7]. An extreme example neoliberal perspective on the waste industry should be seen in a memo signed in 1991 by Lawrence Summers, Chief Economist of the World Bank at the time:

I think the economic logic behind dumping a load of toxic waste in the lowest-wage country is impeccable and we should face up to that... measurements of the costs of health impairing pollution depend on the forgone earnings from increased morbidity and mortality. From this point of view, a given amount of health impairing pollution should be done in the country with the lowest cost, which will be the country with the lowest wages [8].

\section{Circular Economy}

The notion of circular economy (CE) has gained increasing traction amongst sustainability practitioners, policymakers and academics in recent years in response to worsening social and environmental issues, particularly within the waste and recycling sector. Though current perspectives on $\mathrm{CE}$ are wide-ranging and somewhat discursive, there is a general consensus on the growing of the ' $3 \mathrm{R}$ ' principles: namely to reduce, reuse and recycle both energy and materials in a circular flow through an economy [9]. CE has also been defined relationally 
through its opposition to the prevailing 'linear' economy, the latter of which it self-describes as having an 'extract-produce-use-dump' structure.

Digging deeper, the theoretical economic basis of CE is traced to contributions in industrial ecology, environmental economics and ecological economics literatures. CE first gained prominence in industrial ecology, which viewed 'the industrial system and its environment as a joint ecosystem characterised by flows of material, energy and information' and framed sustainability 'in terms of physical rather than monetary flows' [10]. CE then gained currency in environmental economics, an offshoot of orthodox economics which concerns itself with alleviating environmental problems through the regulation of market failures. Finally, the school of ecological economics, conceived as a move away from environmental economics' continued use of methodologically-individualist neoclassical frameworks, is where CE has been finding its most recent theoretical support. As an interdisciplinary field, ecological economics defines itself as the study of "the interactions and co-evolution in time and space of human economies and the ecosystems in which human economies are embedded', and has developed concepts such as ecosystem services, energy economics and weak and strong sustainability [11].

With respect to government policy, the application of CE still appears to be in its early stages, focusing on the recycling of food and waste over the 'higher-level' reduce and reuse principles. Globally, a stark contrast can be seen between the predominately market-based or 'bottom-up' CE policies in Europe and Japan, compared with the control and command or 'top-down' approach favoured in China and other authoritarian states [7, 10]. In Australia, the emerging waste crisis has become a major catalyst for the introduction of CE ideas at all levels of government, such as in the NSW government's Circular Economy Policy Statement: Too Good To Waste [12]. The federal government then moved to complement policies by the states and territories with major federal policy announcements in 2020, which included significant funding and a ban on the export of raw material waste. The opportunities and limitations of these new policies will be analysed in more detail in section 3's case study on Australia's product stewardship scheme for electronic waste.

\section{Political Economy}

Although orthodox economics has dominated the 'contest of economic ideas' over the past several decades with the hegemonic position of neoliberalism, alternative frameworks from the circular economy and political economy literature appear set to swing the balance in a post Covid-19, closed-border world [4]. Modern political economy studies economics from a social science perspective through the analysis of the relationships between capital, labour and the state in historical time - in contrast to orthodox economics' analysis of equilibrium time.

More specifically, political economy of the environment draws largely from Marx's dialectical, historical-materialist method of analysing capitalist economies and their social and environmental impacts. It is argued that over the long term, the forces intrinsic to the process of capital accumulation tend toward crisis and require a restructuring of the political economy [4]. Although the focus has historically been on social crises, this body of social studies literature has undergone arguably the largest and most controversial re-evaluation since the late $20^{\text {th }}$ century due to accelerating environmental crises [13].

The concept of ecologically unequal exchange (EUE) will now be introduced as it bears particular relevance to Australia's waste crisis. As the name suggests, EUE derives from the 
concept of unequal exchange in world-system analysis, the latter of which developed in the 1970s as a multidisciplinary Marxist perspective that identified the overarching capitalist world-system as the primary unit of social analysis [13]. States within the world-system are categorised as either core, periphery or semi-periphery according to their differential strengths in profitability, monopolisation and the international division of labour [14]. These states are then connected by a process of unequal exchange, whereby quasi-monopolistic, highly skilled and profitable production processes in core states systematically appropriate and transform surplus value from less profitable and lower-skilled peripheral and semi-peripheral states [15].

With respect to the waste sector, EUE analyses the counter-tendency in world-systems for core-based waste material and economic processes to be exported and displaced to the periphery [16]. The late Scott Frey was a pre-eminent scholar in this field, contending throughout his career that 'Centrality in the world-system allows countries to externalise their hazards or environmental harms on others', with the implication that 'the transfer of core hazards to the (semi) periphery has adverse environmental and socio-economic consequences ... and it has spawned conflict and resistance, as well as a variety of other responses' [17]. Frey conducted his research in a range of periphery contexts, such as in Chinese e-waste villages [17] and Mexican Maquiladora (tariff and duty free) factories [18].

\section{Methodology}

The CE concept is the overall theme guiding this article's methodology. As introduced above, $\mathrm{CE}$ traces its roots from a multitude of theoretical paradigms, and has similarly taken on a multitude of practical forms in implementation due to factors such as geography and political economy. On a personal level, I experienced these diverse business and governmental interpretations of CE firsthand during a postgraduate field trip to Laos and other personal travels throughout Asia, which in turn influenced my methodological approach in critically analysing CE in my home country of Australia.

My mixed methods approach is best conveyed by outlining the structure of this article, which follows. Section 1 contains the substantive explanation of my methodological approach with a literature review and critical analysis of three distinct theoretical frameworks: orthodox economics, circular economy and political economy. Section 2 is this outline of my methodology. Section 3 moves to an empirical analysis of economic data and trends in the context of Australia's waste crisis. The methods used include my own statistical analysis of UN Comtrade data, qualitative analysis of waste reports, and an evaluation in light of my methodological approach $[19,20]$. Section 4 concludes this paper by analysing and evaluating Australian waste policies with respect to their relationship with the CE concept.

\section{From Externalising Waste to Economic Crisis}

\section{Australia's Waste Industry}

Waste can in the first instance be defined as any material or product that has been discarded in any form through recycling, conversion to energy, and disposal means [20]. Australia's federal National Waste Report (2018) identifies 10 main waste material categories, with metals, hazardous, plastics and food being the main components [20]. The complex electronic waste 
stream is identified separately as 'composite material products' that can contain both recoverable and hazardous materials [20]. A figure from the report illustrates the flow of waste through the domestic industry; flows of waste start from source streams, move through processing within waste infrastructure and eventually end up in either landfill or reprocessing (which occurs both domestically and internationally) Figures 1, 2, 3, 4, 5, 6, 7, 8 .

Electronic waste is an increasingly significant and complex waste stream that has been ascribed many names (e-waste, EoL [end-of-life electrical and electronic equipment], WEEE [waste electrical and electronic equipment], etc.), but can be broadly defined as any device that is operated by battery or power cord [21]. Owing to rapid rates of technological change and consumer uptake of electrical and electronic equipment (EEE) over the past several decades, ewaste has become the fastest growing waste stream globally.

Digging deeper, the e-waste industry can be narrowed further on the scrap metal industry, with scientific research finding that e-waste streams are composed mainly of metal at $51 \%$ [22]. Australia's scrap metals industry is dominated by the globalised firm Sims Metal Management and is heavily reliant on international trade with exports accounting for $66.5 \%$ of total revenue in 2018-19 [22]. This background information on e-waste will be explored further in section 3 with a case study on product stewardship schemes for Australian e-waste [23].

\section{The Economics of Australia's Waste Crisis}

Discourse on a national waste crisis has proliferated amongst Australian media, industry and government spheres since China's implementation of strict waste import restrictions in January 2018. While the use of the term of a 'waste crisis' has become commonplace, its meaning, function and implications are far from universal. How has Australia's waste crisis been understood from media, economic and political perspectives? And how can a critical analysis of the crisis help inform effective policy responses?

Media discourse focuses on a crisis of social legitimation, with investigative reports of fraudulent stockpiling, landfilling and inter-state transporting of waste garnering public outcry and a loss of faith in waste and recycling services [24]. Personal responsibility through the reduction of plastic bag use and generation of household waste is often simplistically reported as the solution, in turn receiving commensurate academic criticism from Slavoj Žižek as an example of 'ideology at its purest' [25]. Government rhetoric on the other hand tends to be more cautious and frames the situation as a 'challenging time' [26].

The most popular framing of the situation, however, is of an economic crisis. This interpretation of the crisis is based on orthodox economic theory and loosely tracks the following trajectory: China's watershed import policies caused a chain of economic effects in Australia and around the world that have brought to light issues regarding the sustainability of the international waste trade.

The first direct effect of China's restrictions was a large fall in scrap metal demanded, which given Australia's heavy reliance on exports, significantly reduced industry revenue [27]. Second, China's share of international demand was so large that global scrap metal prices plummeted as a consequence of the CNS policy [23]. Further exacerbating the domestic industry's profitability woes, buyers of recycled waste material (particularly scrap metal) who used the product as inputs in production, then began substituting domestically recovered materials for cheaper alternatives sourced from abroad [27]. As a result, these economic effects 


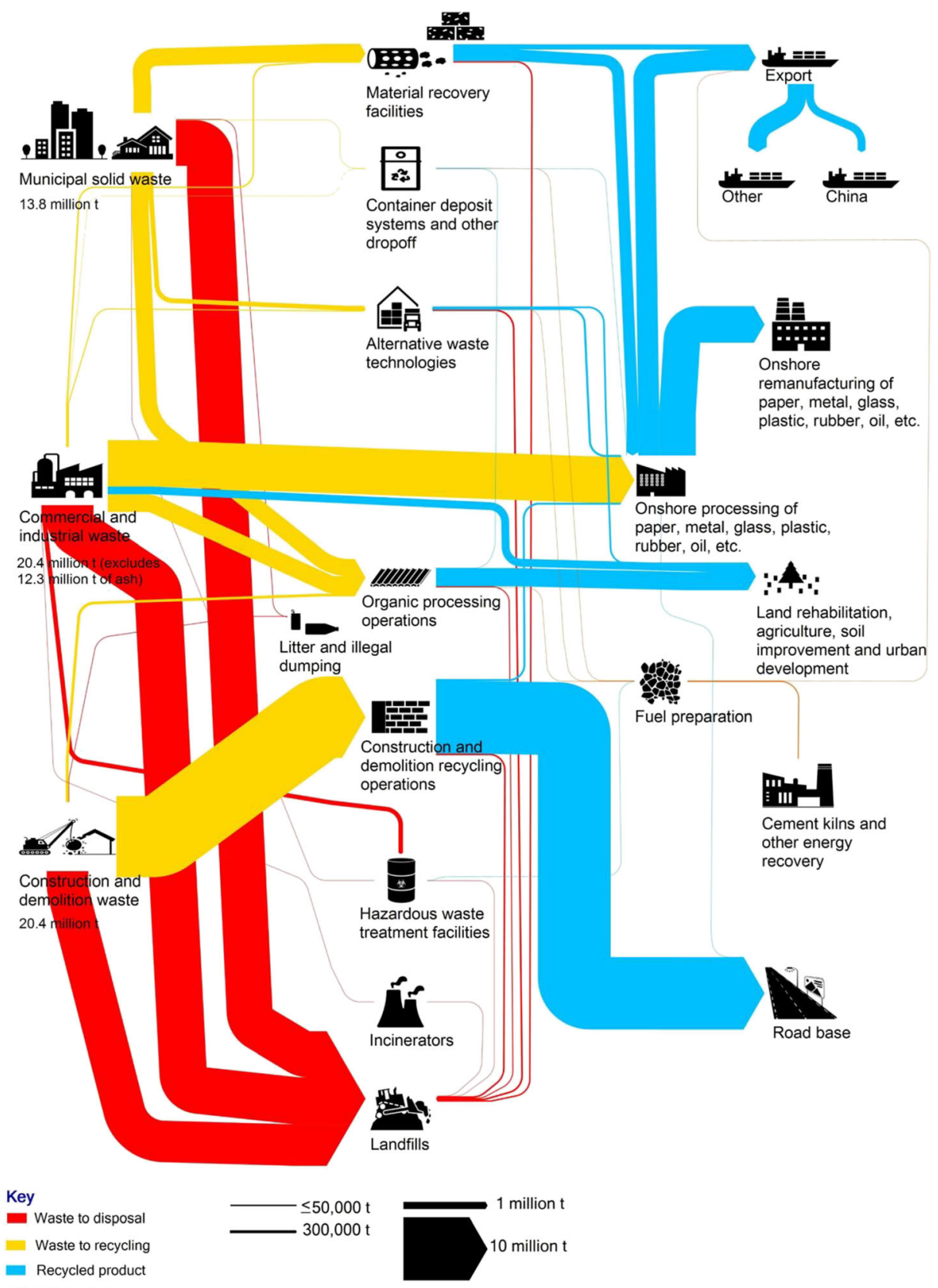

- Energy recovery

Fig. 1 'Waste flows in Australia, 2016-17 (core wastes only; arrow thickness is proportional to flow size)' [20]

culminated in 'absolute chaos in the scrap metal markets with extreme gluts in scrap metal', forcing many businesses to stockpile, landfill and illegally dump recyclable materials [27]. 


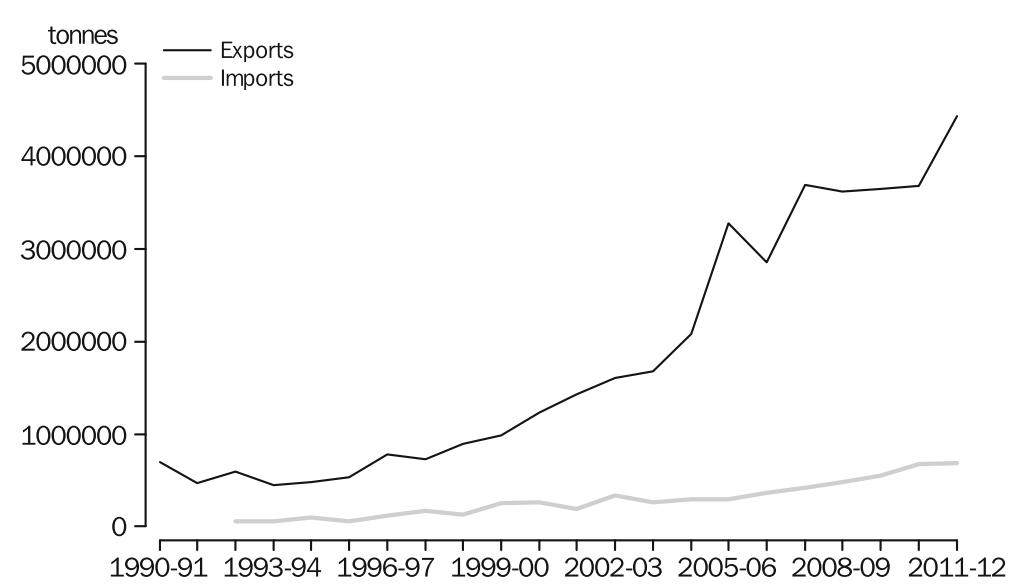

Fig. 2 'International Trade in Waste, 1990-2012' [29]

From an orthodox economics perspective, this crisis can be considered a trough in the business cycle which, with the help of Keynesian macro-economic management, can be resolved if increased government spending helps restore aggregate demand in the macroeconomy. Or, from a business perspective, periods of downturn result in 'consolidation and restructuring activities' that reduce business costs, followed by a recovery as prices fall and demand rises again [27]. While such interpretations assist businesses and governments in addressing the short-run effects of the waste crisis, they tend to lack analytical depth in understanding the structural political-economic dimensions of crises to inform longer-term solutions. This paper contends that short-run and mechanistic accounts of economic crisis where 'many commodities, such as scrap metal, are being purchased at larger volumes, creating greater demand, thereby driving up scrap metal prices' are limited in both their explanatory power and capability to guide long-term recovery [27].

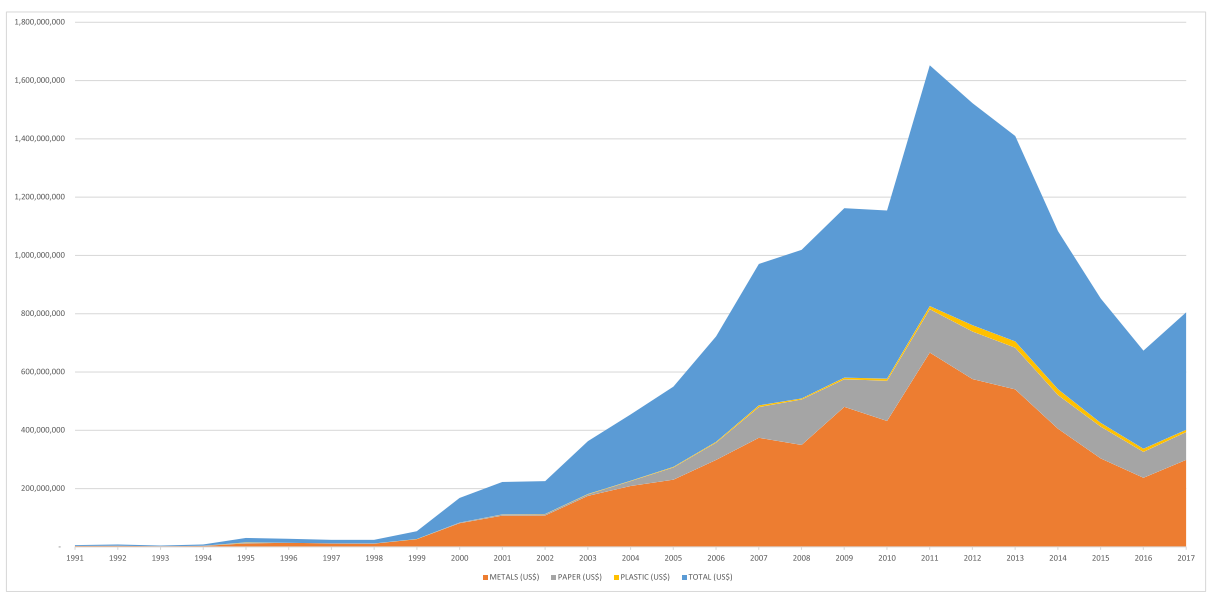

Fig. 3 'Total waste exports from Australia to China by financial value' [19] 


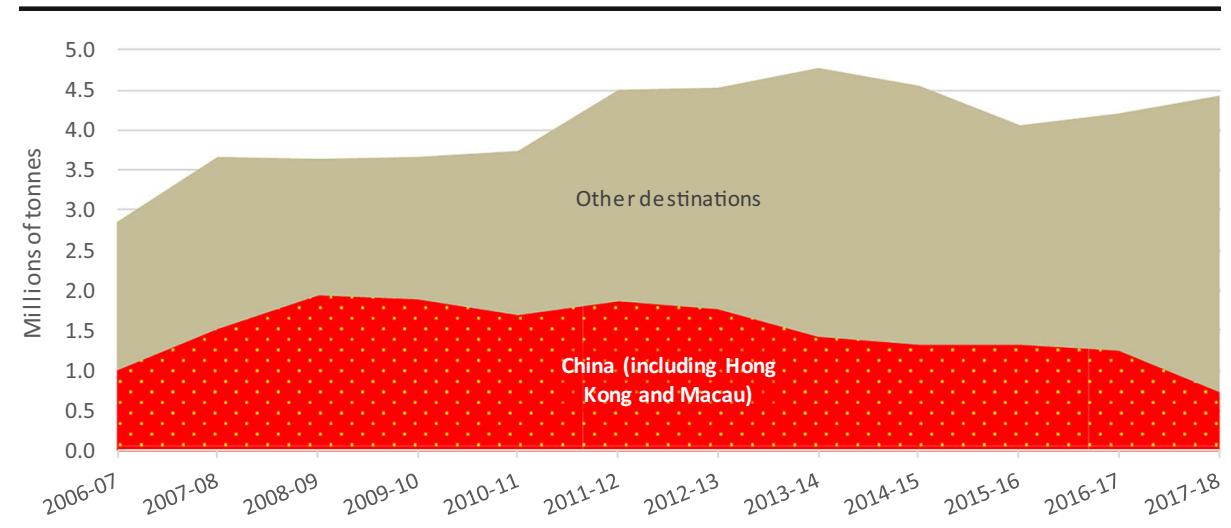

Fig. 4 'Exports of waste from Australia to China and other destinations by financial year' [46]

\section{Externalising Waste to the Periphery}

A political economy perspective on Australia's waste crisis offers a more critical analytical approach by highlighting its global dimensions - specifically Australia's systematic tendency to export and externalise waste to its Asian periphery through a process of ecologically unequal exchange (EUE), or economic imperialism. As a branch of world-systems analysis, EUE's ontological framing places Australia as a core state (similar to developed country) which follows the economic logic of transferring hazardous and harmful 'anti-wealth' to other peripheral and semi-peripheral states (similar to developing and third-world countries, respectively) [28].

Historical data from an Australian Bureau of Statistics report (2013) supports this argument, showing that Australian exports of waste far exceeded imports from 1990 to 2012. In fact, waste exports have been growing at an accelerating rate since 1990, with only the Global Financial Crisis (2007-08) causing a temporary bucking of this trend. The most dramatic rise

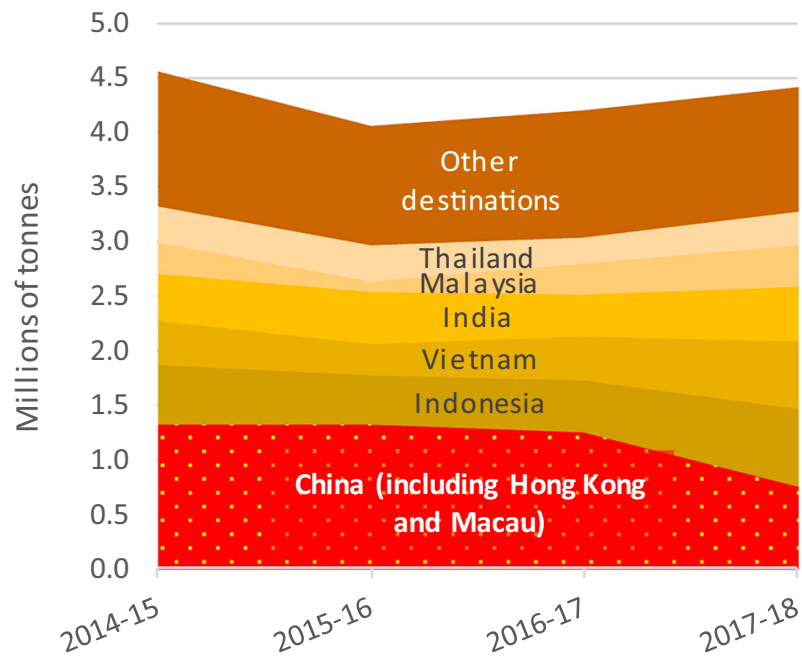

Fig. 5 'Exports of waste from Australia by financial year, showing the top six recipient destinations' [46] 


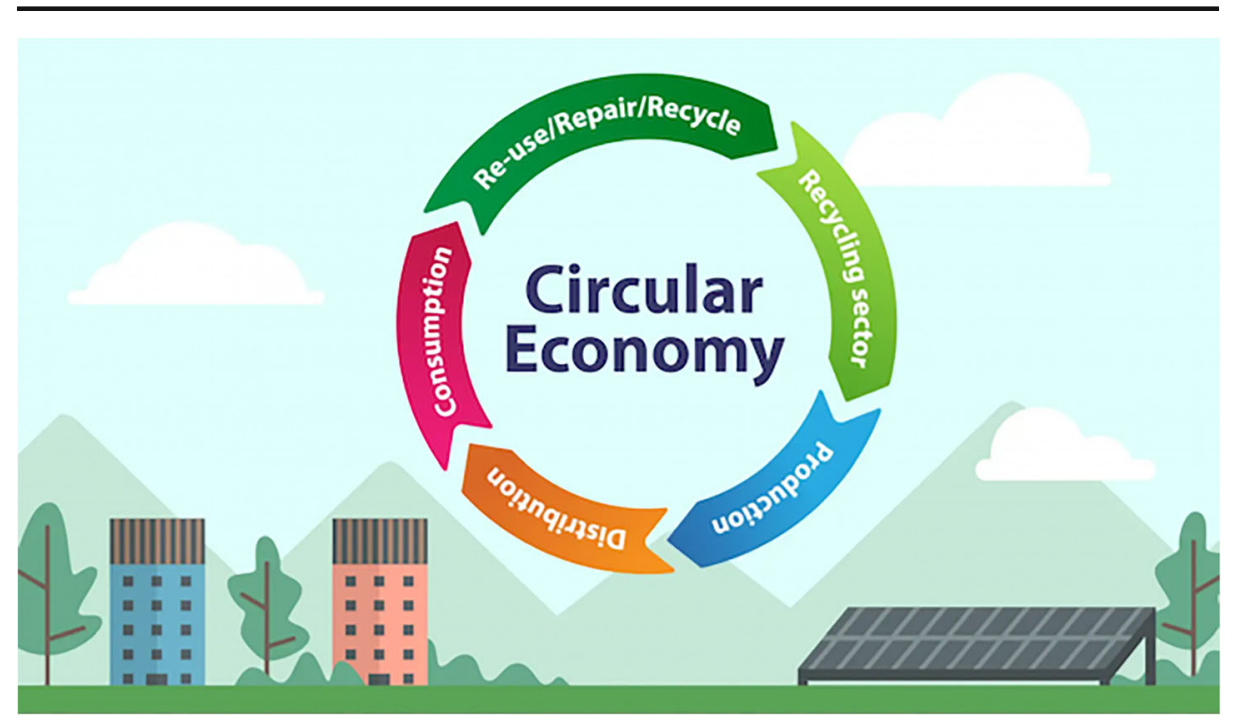

Fig. 6 'Circular Economy’ [33]

occurred at the turn of the millennium with exports more than quadrupling in the 7 years from 1999-00 (\$349m) to 2006-07 (\$1,245m) [29].

Examining Australia's waste trade relationship with China provides further insight into the notion of EUE in relation to economic crisis. In order to fuel 'the fastest sustained expansion by a major economy in history', China's demand for resources (both virgin and recycled/ recovered) grew exponentially during the neoliberal era with the country taking on a major peripheral role as the world's waste sink [30]. The economist notes that 'between 1995 and 2016 Chinese imports of waste grew tenfold, from 4.5m to 45m tonnes' [31]. Bilateral flows of waste between China and Australia fall in line with this trend, with UN Comtrade data

\section{Most preferable}

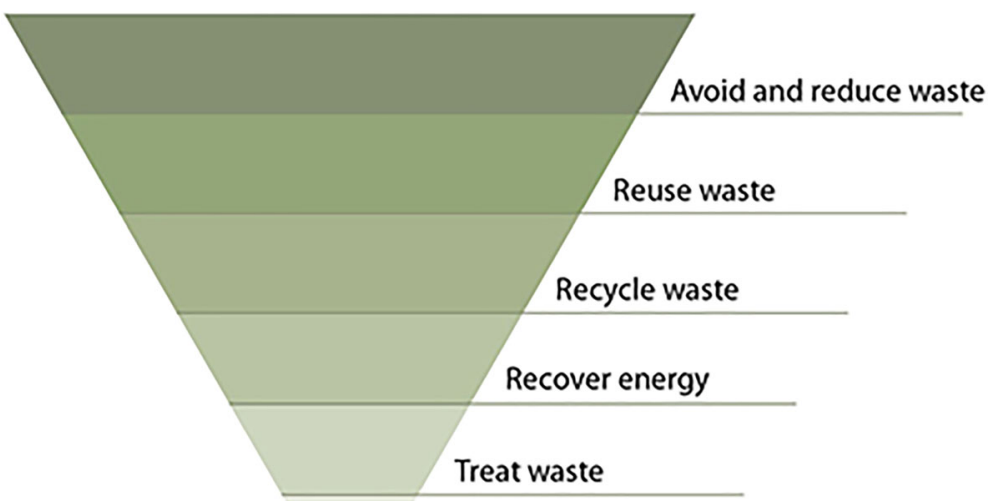

Dispose of waste

\section{Least preferable}

Fig. 7 'Waste Hierarchy' [12] 


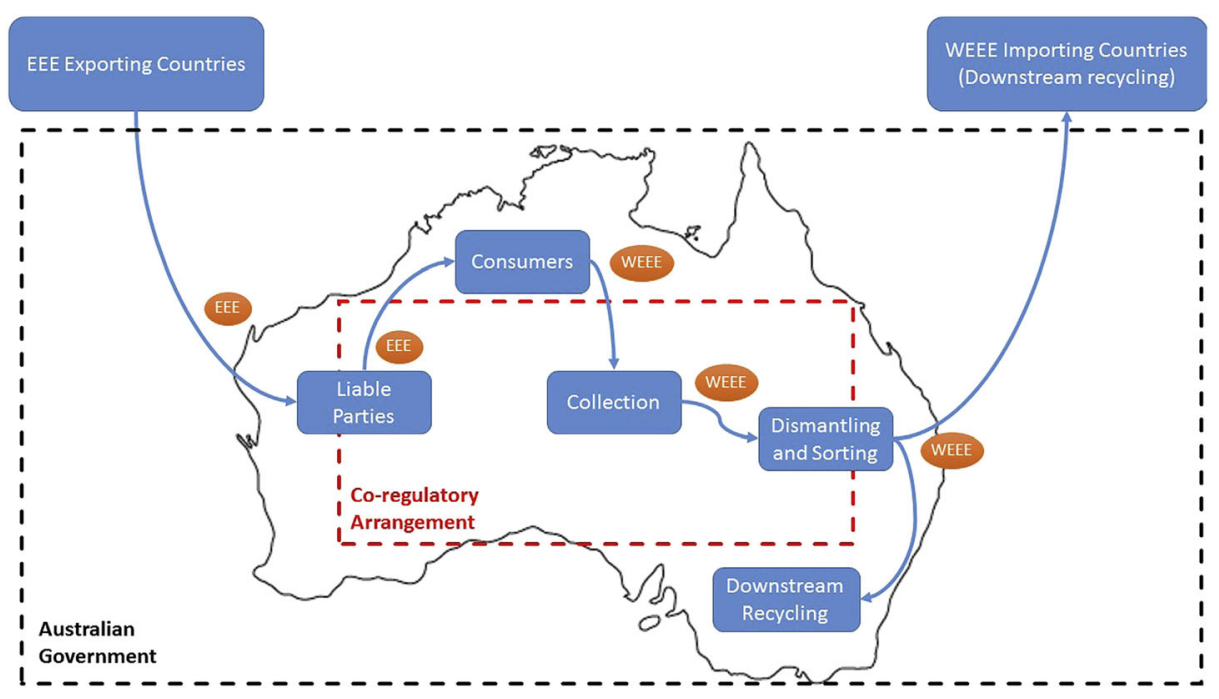

Fig. 8 'Current structure, WEEE flow and responsibility boundaries of the NTCRS' [35]

showing total waste exports from Australia to China growing from negligible amounts in the 1990 s to $\$ 800 \mathrm{~m}$ USD in 2011, with metal exports comprising the largest sub-category ( $\$ 666 \mathrm{~m}$ USD) [19].

A steady decline in Australian waste exports to China has been observed since 2011 due to China's efforts to restrict waste imports. Although China only garnered public attention in 2018 with the implementation of strict waste contamination standards that would effectively ban the import of waste, it has been working on limiting its intake of waste imports for close to a decade through various central government campaigns [2]. The following timeline produced by MRA Consulting (as commissioned by the Australian Council of Recycling) provides a summary of China's policies:

In April 2011, China adopted regulations (known as Article 12) aiming to reduce contamination in imported material In February 2013, the Chinese government decided to aggressively enforce Article 12 to improve the quality of the imported recyclables through 'Operation Green Fence'.

In February 2017, 'National Sword 2017', a 1-year campaign similar to Green Fence, was launched.

On 18 July 2017, China announced the ban of 24 import materials to the World Trade Organisation (WTO).

On 27 July 2017 China announced its intention to 'phase out imports of solid waste (recyclables) that can be substituted by domestic resources' by the end of 2019 .

On 11 January 2018, China confirmed the contamination standards and the ban have since entered into force. The key contamination thresholds include the following:

- $\quad 0.5 \%$ for plastics; scrap paper or paperboard; smelt slag; wood; waste electric motors; wires and cables; metal and appliance scrap; ferrous metals.

- $1 \%$ for non-ferrous metals.

- $0.3 \%$ for automobile scrap. 
On 6 March 2018, 'Blue Sky 2018', an iteration of National Sword, was announced. The campaign will operate to December 2018 and will enforce the ban announced in 2017 [2].

In response to the closing of the Chinese market, EUE predicts that waste, flowing as a commodity through the world-system, would continue following its externalising economic logic to find new markets in other peripheral states [17]. As hypothesised, Australia's waste industry has done exactly this. In fact, Australia's waste exports seemed to be so strongly linked to international markets that exporters were able to 'more than offset' the decline in exports bound for China with 'higher exports to other countries' in the very year China's strict import ban took effect [20]. Data from Blue Environment reveals that the top six recipient nations experiencing an increase in waste imports from Australia in 2018 were all located in the South-east Asian periphery [20]. As such, ongoing developments in Australia's waste crisis concretely demonstrate the attachment of pollution to international flows of capital, made visible through the externalisation of waste [32].

\section{Waste Policy and Neoliberalism}

A political economy perspective strengthens our understanding of Australia's waste crisis by also showing that the aforementioned economic volatility is not, and should not, be reductively separated from the government policies that create various conditions for business in Australia's waste industry. Rather, government policies during the neoliberal era systematically incentivised waste operators to pursue an exportoriented model of business.

Historically, the impact of neoliberalism (or economic rationalism as coined in Australia) involved the deregulation and privatisation of the global waste industry from the 1980s onwards. This saw the widening of transnational connections, with federal policy becoming increasingly vital to providing the political and economic conditions through which the global waste trade could expand. In Australia, the historical role of state and territory government primacy for waste regulation became gradually overtaken by national schemes such as the National Packaging Covenant (1999), Waste Generation and Resource Efficiency Productivity Commission (2005) and National Waste Policy (2009) [20].

More specifically, landfill levies had historically been the most significant form of waste regulation and have been effective in limiting the volume of solid waste entering landfills and raising substantial tax revenue [26]. By using weight-based landfill diversion targets, landfill levies drove a rapid expansion of the waste industry: 'From collection through to sorting, there has been a focus on quantity rather than quality' [26]. Bans and conditional restrictions were also employed by the states and territories to control hazardous and electronic waste entering landfill sites, and further contributed to the glut of waste material being exported overseas [24]. All in all, firms were able to continue expand their profit-making by increasing the quantity of waste diverted away from landfill, even if the waste was of low quality and simply exported for processing overseas.

This section has shown how the externalising logic of globalised waste was spurred on by an expansion of Australia's waste industry as it capitalised on increasing domestic recycling rates. Government policies facilitated this trend, with bans and levy increases on landfill waste disposal contributing to a dramatic expansion of the 
domestic production of recyclable waste. In order to deal with this glut of recyclables in an 'easy' way that would 'increase profit margins', industry operators then often sought to export this material to Australia's Asian periphery due to the lack of a domestic market [26]. Only now, with China enforcing a ban on this waste trade and the South-east Asian periphery following suit, has Australia acknowledged the economic and environmental unsustainability of such waste externalisation.

\section{Australia's Waste Policy in the Circular Economy Transition}

\section{Circular Economy Policy in Context}

A surprisingly obvious relationship can be observed between CE policy on the one hand and waste management principles on the other. As can be seen in the figures above, CE's 'reduce, reuse and recycle' principles are almost identical to the waste industry's 'prevention, reuse, recycle, recovery, disposal' hierarchy. In fact, the latter waste hierarchy preceded the former, first appearing in official waste policy in Europe in 1975 [34], and in Australia in 1994 [5].

Australia's waste industry has been working with these principles decades before the recent interest in CE by gradually moving up the waste hierarchy, starting with bans and limits on waste disposal in landfills in the 1980s, moving to education on recycling and recovery, to most recently using market-based mechanisms to incentivise waste [35]. From this perspective, CE can be seen as attempt to widen the waste hierarchy and apply it to broader issues around water, energy and the general sustainability of the economic system. The application of CE principles in product stewardship schemes will be assessed in a case study on Australian ewaste next.

\section{Australia's Product Stewardship Schemes for E-Waste}

Product stewardship schemes (PSS) are the most recent development in Australian waste policy. As economic instruments that require manufacturers to fund the disposal of their products, these schemes have been 'strongly indicated in situations where a market failure occurs and direct regulation is difficult' [35]. Australia's national PSS was introduced into legislation through the Product Stewardship Act (2011) and was first implemented through the National Television and Computer Recycling Scheme (NTCRS). This legislation required liable firms to fund 'co-regulatory arrangements', which would achieve the recycling obligations by sub-contracting 'first-stage' recyclers of e-waste [36].

As an economic instrument, NTCRS's main achievement was to maximise e-waste throughput and has since far surpassed its legislated collection requirements. This is noted by Dias et al.:

The implementation of the NTCRS has led to many positive outcomes such as increase in the employment in the e-waste recycling sector, an overall increase in e-waste collected and recycled since its inception and, consequently, a significant increase in e-waste diverted from landfills [37].

While these results may initially sound promising, this positivity starts to fade when considering the final destination for the extra e-waste collected. Aligning with this article's 
hypothesis, further research has shown that 'much of the recovered material is exported for reprocessing overseas' with the NTCRS actually contributing to Australia's waste crisis by increasing the amount of waste exported [35]. In the first three years of its operation (FY1416), exports of waste covered by the scheme grew at an average annual rate of $36 \%$, outpacing the average growth of e-waste collection at $21 \%$ [37]. The fact that China was the largest destination for NTCRS exports (43\% of total) further emphasises the policy's unfortunate paradoxical contribution to the recent waste crisis.

Another limitation of the NTCRS has been its lack of impact on 'eco-design' [37]. As an economic instrument, PSS's require firms to simply fund recycling schemes through subcontractors rather than affect internal structural changes, and therefore have 'less of a direct impact on the producer' [32]. Even the European Union's PSS, considered to be 'the world's most comprehensive political response to the harms of WEEE export', falls prey to this policy limitation [32]. As such, it is unsurprising that Australia's still more conservative NTCRS with its less onerous terms of 'shared responsibility for funding and operation, shared between all parties in the supply chain including government, industry and the community', has had little to no impact on the design and supply chain structures of the predominately international manufacturers that dominate the Australian market [35].

\section{Opportunities and Limitations in the Circular Economy Transition}

In response to the waste crisis, Australia's federal government has recently introduced landmark new policies through the Recycling and Waste Reduction Act 2020, which was signed into legislation in December 2020 and come into full effect mid-2024 [39]. Banning the export of some raw materials collected for recycling (plastic, paper, glass and tires), this new law is the Australian government's most clear action to date in transitioning the waste industry towards CE [39]. In addition, the ban has been complemented with new measures to expand existing laws on product stewardship and hazardous waste: namely the Recycling Modernisation Fund, National Product Stewardship Investment Fund (\$10m AUD) and Product Stewardship Centre of Excellence. At this very early stage of the transition, it is important to consider the potential impacts of this promising momentum towards a more circular economy in Australia.

First and foremost, the ban on the export of raw material recyclables will effectively reduce the unsustainable process of EUE, through which Australia systematically externalises its waste materials to the Asian periphery. Though it could be argued that those Asian markets had already begun drying up in the aftermath of China's import ban, Australia's own ban is nevertheless an important market signal that onshore waste processing will in the future be favoured over international markets. Notably, however, the ban only includes some raw material types and excludes all end products (including e-waste) that have been collected for recycling [40]. Speculatively, the reasons for the exclusion of end products from the export ban could be due to an aim to gradually enforce the bans, or a recognition that Australia is severely lacking in domestic manufacturing capacities and thus would likely not be able to find a domestic market for recycled end products. So while the waste export ban will influence a more circular economy in some raw material types, it is far from enforcing a closed-loop circular flow of most waste materials within Australia.

Having considered Australia's new prohibitive CE policy, the next question is how the export ban will be complemented with more supportive measures on the demand side to 
develop domestic waste markets and processing infrastructure. Specificity with respect to approaches from the states and territories is important here, as the smaller economies of South Australia, Western Australia, Queensland and Northern Territory are more lacking in waste processing infrastructure than the larger economies of New South Wales and Victoria. The federal government's aim at a 'national and strategic approach' through a $\$ 190 \mathrm{~m}$ funding commitment to the Recycling Modernisation Fund should be commended here, as it is only through such federal co-ordination towards the development of waste markets and infrastructure that Australia's waste industry will be able to transition towards a circular economy within its national borders [41]. The importance of national co-ordination in Australia's CE transition becomes more apparent when compared to other rising state-led examples, such as in Russia's $\mathrm{CE}$ development through state corporations and China's strict enforcement of CE principles through top-down policy, the latter of which started Australia's waste crisis in the first place [42].

With respect to the 'higher-level' reduce and re-use CE principles, the federal government's recent funding injections will further expand product stewardship schemes in Australia but will do little to encourage eco-design. Quoting Gumley again:

the role of Australian regulation in driving product design changes is very limited... as most of the relevant products are manufactured overseas [35].

As such, bold policy statements that claim 'Manufacturers will be encouraged to rethink how they design products and use resources' show positive signs transitioning to CE principles, but will realistically have little to no impact in Australia [12].

Some final considerations on the scientific and economic theoretical foundations of CE reinforce its limited scope as simply a policy tool to meet economic ends and not a new paradigm of economic theory and practice. First, the scientific principles of CE have been described as 'shaky' at best due to problems associated with three of its fundamental assumptions: (1) waste is never actually 'food' in reality due to entropy, (2) issues of scale when resources and materials are 'fed back' into the ecosphere and (3) changing scientific ideas on waste as 'circular' as knowledge continues to develop [43]. This has led some critics from the physical sciences to argue not only that "the sustainability guarantee of 'circular' solutions is an illusion", but even that "the assumption that 'circular' solutions necessarily lead to sustainable outcomes is wrong" [43].

Second, CE has remained ambiguous in its conceptualisation of the commensurability between 'circular' principles and economic growth. In fact, no substantial development of CE theory exists in academic literature in support of a 'decoupling' from economic growth. Instead, these claims are largely based on business perspectives, such as in the claims by the Ellen MacArthur Foundation \& McKinsey Center for Business and Environment that $\mathrm{CE}$ 'offers a new growth paradigm' by enabling 'growth from within' [44]. The tendency for efficiency gains to rebound into greater overall consumption and production through the 'Jevons paradox' is also not explored in this discourse, despite critical research from the Journal of Industrial Ecology finding that 'circular economy activities can increase overall production, which can partially or fully offset their benefits' [45].

Overall, this section's analysis of CE-informed policies in the context of Australia's waste crisis has shown that the former are effective when implemented as market-based mechanisms stimulating economic recovery, but are limited in their ability to encourage more 'circular' economic practices. The actual waste policies slated for Australia's CE transition (export bans, PSS's, market development and infrastructure funding) are mainly market-based mechanisms 
that essentially differ from previous neoliberal era policies simply in their geographic and/or political orientation, that is, CE gestures towards more domestic industry development in contrast to the former neoliberal era's focus on international expansion [46]. In guiding Australia's recovery from a waste crisis, CE therefore has more of a pragmatic, industryfocused role rather than a lofty theoretical one.

\section{Conclusion}

Waste as an economic commodity is more structurally implicated in Australia's waste crisis than simply as a negative externality — as orthodox economists often contend; waste has been exported to peripheral nations for decades as a low-value and sometimes hazardous commodity, while simultaneously driving the growth and expansion of the domestic waste industry. With China's landmark waste import ban in 2018 providing the impetus for many other peripheral nations to follow suit and 'refuse to be treated as rich countries' waste dumps', many core nations around the world, such as Australia, are finally owning up to the ecologically unequal nature of the global waste trade [46].

Taking a political economy approach, this article has examined the economic drivers of and policy responses to Australia's waste crisis. First, an economic expansion of the waste industry was seen during the neoliberal era as waste management firms took advantage of 'quantity over quality' style government policies to expand both waste collection and profit-making through export-oriented growth. The industry's over-reliance on exports then led to a waste crisis when China and several other South-east Asian countries implemented bans on this waste trade due to its detrimental environmental and economic effects. In order to recover from the waste crisis, waste policy across all levels of government in Australia have since begun championing the principles of $\mathrm{CE}$.

This article's final section concludes by exploring the economic and political relationships between Australia's waste crisis and both historical government policies (the NCTRSAustralia's first product stewardship scheme) and future ones (Recycling and Waste Reduction Act 2020). The onset of Australia's waste crisis has created opportunities by fast-tracking the growth and development of Australia's domestic waste industry and infrastructure, as well as incentivising a more circular flow of waste within national borders. The limitations of this paper are an inevitable consequence of its specific methodological approach. By focusing the study on the Australian context, it is clear that these findings should not be over-generalised as nation-states' waste crises are situated in diverse geographical, political, and even ideological contexts. Furthermore, the ongoing nature of Australia's waste crisis (which could arguably be seen as having not yet concluded) points to inevitable changes in future government policies and economic conditions, forcing me to qualify the findings of this paper as contingent on possible changes in the future.

It is clear that Australia's waste industry has largely followed the ebbs and flows of the global political economy - from the expansion of international trade during the era of neoliberal hegemony leading to the waste crisis in question, to an emerging protectionist, post Covid19 era informed by CE principles to stimulate the growth of domestic markets. Far from some radical change towards environmental sustainability, $\mathrm{CE}$ as adopted in the case of Australia's waste crisis is being used as a 'pivot' in economic policy away from neoliberalism in order to maintain business-as-usual for the waste industry. 
Acknowledgements The majority of this research was performed during a Master of Political Economy dissertation at the University of Sydney from 2018 to 2019. I am extremely grateful for the time and energy of my supervisor, Dr. Rebecca Pearse, in her assistance with completing this dissertation.

Code Availability Not applicable.

Data Availability All data and material have been referenced with their online citations where available.

\section{Declarations}

Conflict of Interest Not applicable.

Ethics Approval Not applicable.

Consent to Participate Not applicable.

Consent for Publication I consent to the publication of this manuscript.

\section{References}

1. Brooks AL, Wang S, Jambeck JR (2018) The Chinese import ban and its impact on global plastic waste trade. Science Advances 4(6):eaat0131. https://doi.org/10.1126/sciadv.aat0131

2. MRA Consulting Group (2018) China National Sword: the role of Federal Government. MRA Consulting Group, Sydney

3. Yesmin, S. (2019). 'Global Waste Crisis: A Rising Threat to Environment'. Modern Diplomacy. Available at: https://moderndiplomacy.eu/2019/12/26/global-waste-crisis-a-rising-threat-to-environment/

4. Stilwell F (2012) Political economy: the contest of economic ideas, 3rd edn. Oxford University Press

5. Bureau of Industry Economics (1994) Plastics recycling: economic issues and implications. AGPS, Canberra

6. Visy. (2017). Waste and recycling industry in Australia: Submission to the Senate Inquiry. Submission.

7. Harvey D (2005) A brief history of neoliberalism. Oxford University Press, Oxford. https://doi.org/10.1086/ 520901

8. United States Senate. (1993). Nomination Of Lawrence H. Summers: Hearing before the Committee on Finance, Senate, 103rd Cong. U.S. Government Printing Office. Washington. Available at: https://www. finance.senate.gov/imo/media/doc/hrg103-41.pdf

9. Piers M (2019) Waste hierarchy index for circular economy in waste management. Waste Management 95 : 298-305. https://doi.org/10.1016/j.wasman.2019.06.014

10. Ghisellini P, Cialani C, Ulgiati S (2015) A review on circular economy: the expected transition to a balanced interplay of environmental and economic systems. Journal of Cleaner Production 114(1):11-32. https://doi. org/10.1016/j.jclepro.2015.09.007

11. Xepapadeas A (2008) Ecological Economics. The New Palgrave Dictionary of Economics, London. https:// doi.org/10.1057/978-1-349-95121-5_2141-1

12. NSW Environmental Protection Agency. (2017). The waste hierarchy. Available at: https://www.epa.nsw. gov.au/your-environment/recycling-and-reuse/warr-strategy/the-waste-hierarchy

13. Foster JB (1999) Marx's theory of metabolic rift: classical foundations for environmental sociology. American Journal of Sociology 105(2):366-405. https://doi.org/10.1086/210315

14. Withers M (2011) Does intra-core conflict structurally facilitate semi-peripheral development? A study of Japanese development during the Cold War. University of Sydney, Sydney

15. Wallerstein I (2004) World-systems analysis : an introduction. Duke University Press, Durham. https://doi. org/10.1215/9780822399018

16. Frey RS (2015) Breaking ships in the world-system: an analysis of two ship breaking capitals, AlangSosiya, India and Chittagong, Bangladesh. Journal of World-Systems Research 21(1):25-49. https://doi.org/ 10.5195/jwsr.2015.529

17. Frey RS (2012) The e-waste stream in the world-system. Journal of Globalization Studies 3(1):79-94

18. Frey RS (2003) The transfer of core-based hazardous production processes to the export processing zones of the periphery: the maquiladora centers of Northern Mexico. Journal of World-Systems Research 9(2):317354. https://doi.org/10.5195/jwsr.2003.236 
19. [dataset] UN Comtrade. (2019). UN Comtrade Database. Available at: https://comtrade.un.org/data/

20. Blue Environment Pty Ltd (2018) National Waste Report 2018. Department of the Environment and Energy, Canberra

21. Perkins D, Brune Drisse M-NN, Sly P (2014) E-waste: a global hazard. Annals of Global Health 80:286295. https://doi.org/10.1016/j.aogh.2014.10.001

22. Munro-Smith, H. (2018a). Scrap metal recycling in Australia. IBISWorld.

23. Munro-Smith H (2018b) Waste remediation and materials recovery services in Australia. IBISWorld, Sydney

24. Cormack L (2016) NSW waste still travelling across state borders prompting. EPA investigations, Sydney

25. Zižek S (2008) Examined life [Motion Picture]. Zeitgeist Films, Canada

26. Senate Standing Committees on Environment and Communications (2018) Never waste a crisis: the waste and recycling industry in Australia. Commonwealth of Australia, Canberra

27. GeoSource (2018) Global scrap market prices increasing and stabilizing. GeoSource, Inc., Erie

28. de Bruyn C (2004) Australia's position in the world-system: the historical adoption of corporatist public policy and Australia's subsequent movement between the core and semi-periphery. Griffith University, Mount Gravatt

29. Australian Bureau of Statistics (2013) Waste Account, Australia, Experimental Estimates - 4602.0.55.005. Commonwealth of Australia, Canberra Available at: https:/www.abs.gov.au/AUSSTATS/abs@.nsf/ DetailsPage/4602.0.55.0052013?OpenDocument

30. The World Bank. (2019). The World Bank In China . Available at: https://www.worldbank.org/en/country/ china/overview $\backslash$

31. The Economist (2017) China tries to keep foreign rubbish out. United Kingdom, London

32. Surak S (2016) Capitalist logics, pollution management, and the regulation of harm: economic responses to the problem of waste electronics. Capitalism Nature Socialism 27(1):106-122. https://doi.org/10.1080/ 10455752.2015 .1136663

33. Inside Waste. (2019). New efforts to boost a circular economy are underway at the CEIN . Available at: https://www.insidewaste.com.au/index.php/2019/04/23/new-efforts-to-boost-a-circular-economy-areunderway-at-the-cein/

34. Council of the European Union. (1975, July 15). Council Directive 75/442/EEC of 15 July 1975 on waste. Brussels

35. Gumley W (2016) Using environmental taxation to improve outcomes for e-waste in Australia. In: Stoianoff NP, Kreiser LA, Butcher B, Milne JE, Ashiabor H (eds) Market instruments and the protection of natural resources. Edward Elgar Publishing, Northampton, pp 124-139. https://doi.org/10.4337/9781786431219. 00019

36. Environment Protection and Heritage Council (2010) National waste policy: less waste, more resources implementation plan. Commonwealth of Australia, Canberra

37. Dias P, Bernardes AM, Huda N (2018) Waste electrical and electronic equipment (WEEE) management: an analysis on the Australian e-waste recycling scheme. Journal of Cleaner Production 197(1):750-764

38. Ongondo F, Williams I, Cherrett T (2010) How are WEEE doing? A global review of the management of electrical and electronic wastes. Waste Management 31(4):714-730. https://doi.org/10.1016/j.wasman. 2010.10 .023

39. Department of Agriculture, Water and the Environment (2020a). Investing in Australia's waste and recycling infrastructure. https://www.environment.gov.au/protection/waste/how-we-manage-waste/ recycling-modernisation-fund (accessed 17 Jan 2021).

40. Downes, J., Giurco, D., \& Read, R. (2020). Australia's waste export ban becomes law, but the crisis is far from over. The Conversation. https://theconversation.com/australias-waste-export-ban-becomes-law-butthe-crisis-is-far-from-over-151675 (accessed 17 Jan 2021)

41. Department of Agriculture, Water and the Environment (2020b). Waste Export Ban Discussion Paper November 2019. https:/www.environment.gov.au/system/files/consultations/bf403fda-b6d7-4476-9c6f5627502d52a4/files/waste-export-ban-discussion-paper-november-2019.pdf (accessed 20 Jan 2021)

42. Fedotkina O, Gorbashko E, Vatolkina N (2019) Circular economy in Russia: drivers and barriers for waste management development. Sustainability 1(20):5837. https://doi.org/10.3390/su11205837

43. de Man R, Friege H (2016) Circular economy: European policy on shaky ground. Waste Management \& Research 34(2):93-95. https://doi.org/10.1177/0734242X15626015

44. Ellen MacArthur Foundation \& McKinsey Center for Business and Environment. (2015). Growth within: a circular economy vision for a competitive Europe. Stiftungsfonds für Umweltökonomie und Nachhaltigkeit

45. Zink T, Geyer R (2017) Circular economy rebound. Journal of Industrial Ecology 21(3):593-602. https:// doi.org/10.1111/jiec. 12545 
46. Department of Agriculture, Water and the Environment (2020c). National Product Stewardship Investment Fund. https://www.environment.gov.au/protection/waste/product-stewardship/national-productstewardship-investment-fund (accessed 20 Jan 2021) 